\title{
What They Reveal about Class Differences and the American Dream
}

JONATHAN LATHEY

$\mathrm{R}$ obert Putnam observed that social class differences, now more than ever, determine the life outcomes of American children. ${ }^{1}$ Putnam reported evidence that the American Dream is in crisis for children born into lower-class families-these children have far fewer opportunities for success. This might suggest a loss of a survival narrative for these children.

Moreover, early literacy researchers have documented a "knowledge gap" dividing children from rich and poor families. ${ }^{2}$ This paper explores recent Newbery Medal-winning novels with respect to class differences and their relationship to the American Dream.

Literature, including our best children's literature, influences how we view the world. In 2012, subject experts and curators at the Library of Congress (LOC) identified eighty-eight books they believed shaped American society. ${ }^{3}$

Inspection of the LOC list reveals a handful of books written for children. Titles on the list include Mark, the Match Boy by Horatio Alger Jr.; Charlotte's Web by E. B. White; The Cat in the Hat by Dr. Seuss; and A Wrinkle in Time by Madeline L'Engle. The list also identifies three children's picture books that have shaped America, including Goodnight Moon by Margaret Wise Brown.

Of these books for young readers, Mark, the Match Boy by Horatio Alger Jr. most closely articulates our traditional understanding of the American Dream. ${ }^{4}$ Alger's dime novels, popular in the late nineteenth century, portrayed boys and young men who worked their way out of poverty. Moving into a more respectable position in society required the support and encouragement of a person who had himself improved his own position.

Mark, the twelve-year-old former seller of matches, was assisted by Richard, a former boot black, who adopted the younger boy as his ward. Richard was a young man who read books, saved money, and refrained from drinking and gambling.

Mark, the Match Boy described a process of self-improvement that included a readiness to benefit from such opportunities as were available in a difficult urban environment. Thus, Richard and Mark attended Sunday school where they became friendly with a wealthy merchant who would regularly invite them to dine at his house.

Richard and Mark were exposed to models of socially accepted manners and speech patterns through social interaction and personal relationships with members of this uppermiddle-class family. In fact, the thirteen-year-old daughter of the wealthy merchant was attracted to Richard, who had become a successful office worker at a counting house. It

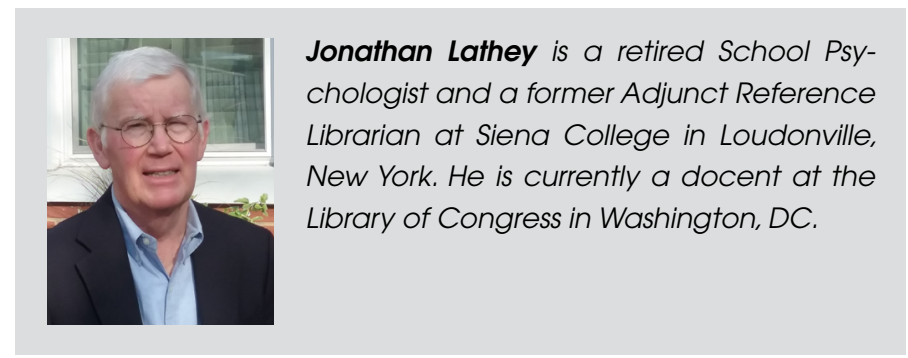


is important to note that the protagonists in Alger's novels-familiar with the degradations of poverty-sought a sense of self-respect and decency in society, rather than the acquisition of great riches.

Critics have suggested that Alger's books are of "little literary merit." ${ }^{5}$ Recent guides to children's books and handbooks of children's literature make no mention of his work. ${ }^{6}$ However, that this title was selected by the LOC as an influential American book reminds us of our abiding belief in the positive relationship between social and educational opportunities and life outcomes.

In this paper, I explore class differences between middle-class and lower-class protagonists as portrayed in recent Newbery Medal books. Our sample includes ten medal-winning novels published between 2004 and 2015; these titles are listed in table 1 .

Three themes emerged that guided the analysis. Themes of survival, the restorative power of narrative, and the importance of knowledge acquisition were suggested by the identification of favorite books by three of our protagonists. As it turned out, these favorite books were titles included in the 2012 LOC list of books that shaped America. Young protagonists in three Newbery Medal winners identified a favorite book that in some way shaped their understanding of the world. The protagonist in Kira-Kira admired The Call of the Wild; in The Higher Power of Lucky, the protagonist read the 1939 Alcoholics Anonymous tome; and the protagonist in When You Reach Me carried a copy of $A$ Wrinkle in Time in her backpack, which, I suggest, anticipates the importance of knowledge acquisition in academic achievement.

These three books that appear on the LOC list-and are admired by three current Newbery protagonists-point to enduring themes, issues, and concerns of American children. Thus, class differences as depicted in our sample of recent Newbery Medal winners are examined in terms of knowledge acquisition and storytelling-and their implications for survival in our changing world.

\section{Theme: Survival}

Consider first what our Newbery novels tell us about social and economic survival, particularly in a difficult economic landscape.

For a school assignment, Katie Takeshita in Kira-Kira by Cynthia Kadohata (Newbery Medal, 2005) gave her interpretation of The Call of the Wild, a story of survival: "Tonight I was supposed to write a book report on The Call of the Wild. It was my most favorite book I ever read, so I thought the report would be easy. The question we were supposed to answer in our report was, What is the theme of The Call of the Wild?"7

Katie concluded that loyalty was the theme, as in being loyal to good people. The theme of survival and loyalty represented a sensitive issue for Katie and her Japanese American parents attempting to survive as workers in the poultry industry in rural Georgia in the 1950s.

Katie described the long hours her parents worked to help buy a modest house and to pay for Katie's older sister's medical bills. Katie observed her mother at work at a poultry processing plant in southern Georgia: "Then she sliced the drumsticks from the thighs and sent the drumsticks down one conveyor belt and the thighs down another. At the exact moment that she finished, another chicken arrived and she cut the legs off it. Over and over. I couldn't see her face, but the faces of the workers I could see were blank, perfectly so." ${ }^{8}$

The fear of ending up as an employee working side by side with lower-class workers was also expressed in Criss Cross by Lynne Rae Perkins (Newbery Medal, 2006)..$^{9}$ Judging from the music on the radio (The Mamas and the Papas) and the popular literature of the day (Jonathan Livingston Seagull), Criss Cross was set around 1970. Criss Cross has to do with the psychological development of the protagonist Debbie, fourteen, and her friends such as Hector, who was learning to play the guitar and write songs.

Whereas the small town depicted in Criss Cross appeared safe and a good place to come of age in a middle-income family, there was an awareness of class differences and their implications for living a full life. Hector's older sister Rowanne articulated these concerns. She was preparing to attend college at the end of the summer, and she had a summer job typing information into a computer, where she was surrounded by young women of the working class. Rowanne was perplexed when she learned that her coworkers accepted this mindnumbing work as normal-as what you do after high school. The young workers talked about their boyfriends and little else. "Because they're basically nice people, they want to include me. They just can't imagine why anyone would read a book of their own free will." ${ }^{10}$ The reader of this postmodern novel 
might conclude that—beyond a gap in opportunity—a lack of imagination is perceived as characteristic of the working class.

\section{Theme: Power of Narrative}

Let us consider next the power of narrative to provide a sense of continuity and purpose for our lives. Our recent Newbery protagonists appeared sophisticated in their developing selfawareness, and this sophistication is reflected in their keen interest in storytelling, song lyrics, and poetry.

Ten-year-old Lucky, the young protagonist in The Higher Power of Lucky by Susan Patron, lives with her French guardian in Hard Pan, a small town near the Mojave Desert. ${ }^{11}$ Lucky eavesdrops on recovering alcoholics and gamblersshe listens carefully to their stories about hitting rock bottom and, in some cases, finding a higher power to restore them to sobriety and health. Lucky carried in her backpack her favorite book-a copy of Twelve Steps and Twelve Traditions, a reference to the Alcoholics Anonymous materials published in 1939. This fifth-grader came to appreciate the restorative value of shared stories.

Like Lucky, Katie Takeshima in Kira-Kira hoped that stories would help her organize her understanding of the world. The Takeshita family had experienced racial prejudice as they moved from place to place seeking work: "I thought of all those stories I had to read for school and the questions the teachers always asked. What is the theme? What does the story mean? Why did the characters act in a certain way? We whizzed by the pretty houses. It seemed that at this moment I was inside a story. This was the story of my life, and I did not know what any of it meant."12

Dead End in Norvelt by Jack Gantos won the Scott O'Dell Award for Historical Fiction as well as the 2012 Newbery Medal. ${ }^{13}$ Young Jack grew up in Norvelt, Pennsylvania, a town created for people of low income by the federal government during the Great Depression. Jack spent the summer of 1962 helping Miss Volker, the county medical examiner, write obituaries for the local newspaper.

Jack's family had little disposable income. The father, a contractor, drove an old Chevy truck and spent the summer assembling a small army-surplus airplane. His mother attempted, unsuccessfully, to barter for goods with her neighbors. The father talked about moving the family to Florida, where there were better paying jobs.

At the end of the summer, young Jack perceived a change in himself. Like Randall in Richard Russo's 1986 novel Mohawk, Jack was a thoughtful lad who struggled to make sense of life in a small mill town that by the 1960s had lost jobs and a way of life. ${ }^{14}$

Typing obituaries, Jack learned the stories of people who had lived in his community. Jack would benefit from the lessons of life and history as experienced in a small town-and in the end he would be prepared to reject the authority of his father when it was arbitrary or foolish.

What about stories portraying the working poor? Our sample of Newbery literature provides only limited insight into the hardships associated with poverty. The picture book Last Stop on Market Street, written by Matt de la Peña, places the reader in the center of urban poverty. A grandmother and her grandson take public transportation after a church service to a community center where they help serve food to the needy. En route, the young protagonist asks, "How come it's always so dirty over here?" The reader's attention is drawn to the decay by verse: "Crumbling sidewalks and broken-down doors, graffiti-tagged windows and boarded-up stores." 16

In his survey of public schools serving the children of the poor, Jonathan Kozol reported on the lack of literature in the lives of the lower class. ${ }^{17}$ Kozol found that many schools had no libraries. The instruction in reading too often reflected a narrow curriculum, with emphasis on drill: "Teachers who come into elementary education with some literary background tell me that they sometimes feel they are engaging in a complicated kind of treachery when they are forced repeatedly to excavate a piece of poetry or any other literary work of charm or value to extract examples of official skills that have some testable utility." ${ }^{18}$

Kozol described the lack of inspiration he observed in these classrooms: "In a kindergarten class, the children were chanting consonant sounds when I arrived, then read without emotion from a story in a phonics book that had only a rudimentary story line and no apparent literary qualities but that employed the sounds they were supposed to learn that day. 'Who can tell me the main characters?' the teacher asked them after they had come to the conclusion of the story. Three or four children answered this and almost all her questions. Most of the others simply stared at her with faces blank."19

\section{Theme: Knowledge Acquisition}

In our analysis, recent Newbery literature is clear about the importance of knowledge acquisition in preparing the child for academic learning. This theme is at the heart of the "knowledge gap" between rich and poor students. ${ }^{20}$

Robert Putnam described in Our Kids class-based parenting practices, including the middle-class effort to build cognitive skills in their children. The parents of our recent Newbery protagonists can be seen modeling, encouraging, and cultivating imagination, interest, and the deliberate acquisition of knowledge.

Rebecca Stead's novel When You Reach Me won the Newbery Medal in 2010. ${ }^{21}$ Miranda, the protagonist, is a sixth-grade student in a public school in the Upper West Side of Manhattan in the late 1970s. Miranda perceives herself and her peers, it 
seems, as if they were enrolled in a gifted and talented program. Her classroom works as a team on a scale model of a city block; classmate Jay Stringer is a twelve-year-old genius who helps plan the project.

Miranda is intellectually intense, with strong interests, beliefs, and a dedication to learning. She helped her mother prepare for competition on a television show that rewarded quick access to factual information. Members of Miranda's peer group routinely refer to categories, constructs, concepts, and theoretical perspectives, as they entertain imaginative, sometimes unusual, ways of construing events. In a final chapter, her intellectually competitive mother is accepted into law school.

Miranda's favorite book is A Wrinkle in Time, the 1963 Newbery Medal winner by Madeleine L'Engle. ${ }^{22}$ She carries a copy of the book in her backpack, and for Christmas she receives an autographed first edition.

A Wrinkle in Time anticipated the role that knowledge has come to play in the lives our children. This classic work was published in 1962, a decade before the widespread interest in schooling, academic work, and the acquisition of knowledge. ${ }^{23}$ L'Engle's novel, I suggest, forecasts the importance of imagination, interest, strategy, and the deliberate acquisition of knowledge in our knowledge-based economy and a world transformed by the computer. ${ }^{24}$

The parents of Meg, the protagonist, were scientists conducting original research; Meg showed an early aptitude for mathematics. Conceptual ability was, of course, essential to this story, which entailed traversing the unknown. Meg's parents administered IQ tests to her and her younger brother, and the scores confirmed their suspicion of high intelligence. Meg asked her father about her intelligence quotient. "That I'm not going to tell you," he said. "But it assures me that both you and Charles Wallace will be able to do pretty much whatever you like when you grow up to yourselves. You just wait till Charles Wallace starts to talk. You'll see." 25
Child-rearing practices that promote the development of attitudes and skills conducive to school learning-notably vocabulary development-contribute to what Susan B. Neuman calls a "knowledge gap," which presumably underlies an achievement gap, between children of middle-class and poor families. ${ }^{26}$

Whereas Meg's parents believed that high intelligence, as measured by an IQ test, would assure positive life outcomes, the behavior of our recent Newbery Medal protagonists and their parents is more in line, I would argue, with the results of recent novice-expert differences research. ${ }^{27}$ Thus, we see a class-based approach to parenting that encourages interests, strategy, and deliberate practice in a quest for ability and talent.

Dedication to the development of talent is evident in The Crossover by Kwame Alexander. ${ }^{28}$ The 2015 Newbery Medal winner, written in rap, is about a pair of African American twins who play basketball. Josh Bell is the talented dribbler, who seeks to follow in his father's professional basketball footsteps. He is a middle-school student who has his sights on elite basketball programs like Duke or North Carolina. His mother is Dr. Bell, the school's assistant principal. Josh takes school seriously. Beyond that, Josh devotes hours to the deliberate practice of basketball skills; he develops his talent under the critical eyes of both his basketball coach and his father.

Thus, our Newbery protagonists are supported in their intellectual curiosity and their quest for knowledge. Lucky wanted to be a biologist; her hero was Charles Darwin. Her best friend, Lincoln, spent hours acquiring the art of knot tying. He joined a knot-tying society and subscribed to a magazine dedicated to knots. Lincoln, also a fifth-grader, could tie beautiful knots after years of practice: "Now she knew that Lincoln was really an artist, who could see the heart of a knot." 29

\section{Discussion}

Over the past fifty years, beginning with President Lyndon B. Johnson's War on

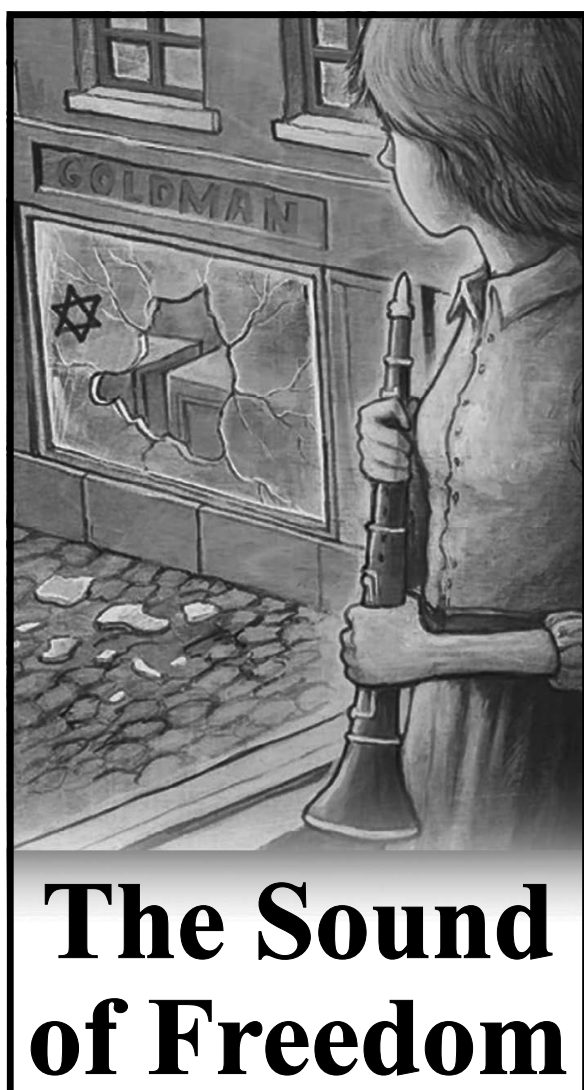

- KATHY KACER •

As Jews, Anna and her family must find a way to escape from the growing danger in pre-war Poland.

"A needed addition."

—School Library Connection, $\star$ starred review

"A fine historical fiction addition to all library shelves."

-School Library Journal

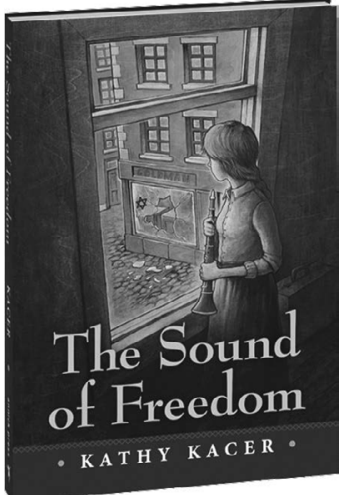

Ages 9-12

978-1-55451-969-9 pb / 978-1-55451-970-5 hc

Read an excerpt on our website

- annick press www.annickpress.com

Distributed by Publishers Group West AN INGRAM BRAND 1-866-400-5351 
Poverty, various state and federal programs have attempted to break the correlation between social class and achievement in the classroom; however, class differences with respect to academic achievement persist. Our award-winning novels were published in the wake of Kozol's 2005 nonfiction book The Shame of the Nation: The Restoration of Apartheid Schooling in America. Ten years later, Robert Putnam reminded us again of the role of social class in accounting for differences in school performance.

The implications of class differences in school learning extend into adulthood. The National Endowment for the Arts (NEA), based on its survey of the reading habits of American adults, issued a report titled "Reading at Risk." ${ }^{30}$ The report found that better-educated adults-adults with more knowledgewere much more likely to read fiction than those of a lower economic status. These findings suggest that literary reading plays a greater role in the lives of the well educated. The survey found, for example, a strong correlation between reading literature for pleasure and community participation.

We live in a world transformed by the computer. The rise of the knowledge-based society has made the relationship of survival and knowledge acquisition ever more important. ${ }^{31}$ Those of the so-called creative class are able to capitalize on their prior knowledge and skills to engage in creative work. ${ }^{32}$ The creative class is characterized by talent, tolerance, and technology; as a group, they are imaginative, mobile, and resourceful.

Our recent Newbery protagonists are aspirants to the creative class. These protagonists are motivated by their passion and interests, though they appear to operate under some stress. Miranda blushed when she was under scrutiny. Jack Gantos, another sixth-grader, had nose bleeds when under pressure. There is a sense of urgency in their application of wit and imagination to their various interests and projects.

As a group, our contemporary Newbery protagonists become more thoughtful with development, and they continue to view imagination as an asset. In fact, they show tolerance toward others who are perhaps a bit different, weird, or strange.

Kate DiCamillo won the 2014 Newbery Medal for her novel Flora and Ulysses. ${ }^{33}$ Flora is a girl with a strong imagination, a storyteller like her mother, who is a writer. Flora imagines a world with a flying squirrel who can write poetry. Flora's mother characterizes her daughter as follows: "Flora is very lonely. She spends far too much time reading comics. I've tried to break her of her habit, but I'm very busy with my novel writing, and she is alone a lot. I'm worried that it has made her strange." ${ }^{34}$ Flora befriends the boy next door named William Spiver, who she believes is "truly, profoundly strange." 35

By contrast, consider Fern in Charlotte's Web, the 1953 Newbery Honor book by E. B. White. ${ }^{36}$ Fern's mother believed that it was not normal or natural for her daughter to spend so much time engaged in fantasy, listening to the stories of farm animals. Mrs. Arable was reassured by a visit to old Dr. Dorian. In time, Fern abandoned her rich fantasy life, and she began to grow up. Her interests shifted to her boyfriend Henry and, presumably, to romantic fantasies about the conventional life she and Henry could have together in the America of the 1950s.

On the other side of the knowledge gap, as documented by Susan B. Neuman, are children of the working poor. Kozol found in the typical public school serving children of minority and working-class families a perfunctory interest in knowledge: "Hours that might otherwise have been devoted to instruction are consumed in restless effort to position little chunks of subdivided knowledge in acceptable containers; and the ritual continues often after children are dismissed and teachers are obliged to stay at school until late afternoon in order to compile inventories of the outcomes they have named and, once a year at least, participate in meetings at which every separate inventory must be reconciled and unified into a single statement of collective purpose." ${ }^{37}$

The parents of the protagonists in recent Newbery Medal winners, including a writer, a school principal, a professional basketball player, a contractor, and a law-school student, promote a culture of achievement, as described by Neuman. ${ }^{38}$ The early literacy researcher describes the resources that middle-class parents invest in their children-an investment that results in a knowledge gap between children from middle-class and children from low-income families. ${ }^{39}$

In their approach to child rearing, middle-class parents value imagination over obedience. Middle-class parents show "remarkable intuitive strategies" as they seek to foster the talents and interests of their children. ${ }^{40}$

This remarkable intuition is, of course, based in some interest and knowledge of child development. Imagine what strategies the educated parent might bring, for instance, to the reading of Goodnight Moon, which was selected by the LOC as an influential book. ${ }^{41}$ A single (or literal) reading of this 1947 picture book would provide the young child with little knowledge.

However, the strategic parent who rereads this book to her child night after night might use the pictures and the rhythm of the text to engage the child in a conversation. Rereading would assure the child about the permanence of the story; rereading would also reassure the child as to the continuity of the attention and interest of the parent. Rereading this bedtime story, the middle-class parent can establish a dialogue of questions and answers that stimulates interest, draws attention to detail, and helps build a foundation of understanding.

An interest in having parents foster learning outside of school coincides with the "excellence movement" in education that emerged in the 1980s. First Lessons: A Report on Elementary Education in America, written by former US Secretary of 
Education William Bennett, called for empowering parents and promoting their central role in the education of their children. ${ }^{42}$

The report recognized the importance of knowledge learned outside of school: "We expect—and should expect-parents to engage themselves directly in their children's education: to read to them if they can, to ask others to read to them if they cannot, to encourage children to read on their own, to meet with teachers, to ensure that homework gets done, to furnish necessary supplies and materials, perhaps above all to convey to their children-not just once, but incessantly-the immense value that they, the parents, assign to a good education." ${ }^{33}$

Our sample of recent Newbery protagonists reveals that they are motivated by a desire to avoid the repetitive, unimaginative, and mind-numbing work that they associate with the working poor. Instead, they view the world in terms of possibilities. As a matter of social justice, they may provide service to the poor, as depicted in Last Stop on Market Street.

However, consistent with Putnam's observations in Our Kids, the current Newbery protagonists show us little by way of meaningful social interaction or friendship with their peers of the lower or working class.

Older Newbery Medal-winning literature confirms Putnam's conclusion that there was greater interaction among children across social classes fifty or sixty years ago. For instance, recall A Wrinkle in Time, published in 1962. Meg, the protagonist, was joined in her adventure to find her father lost in space by her younger brother and by a fellow student named Calvin O'Keefe.

Whereas Meg's mother was an educated woman, a scientist who provided her children with a comfortable home, Calvin described his own mother in terms more characteristic of poverty: "In front of the sink stood an unkempt woman with gray hair stringing about her face. Her mouth was open, and Meg could see the toothless gums, and it seemed that she could almost hear her screaming at two small children who were standing by her. Then she grabbed a long wooden spoon from the sink and began whacking one of the children." ${ }^{44}$ Calvin, who was popular, athletic, and bright, was-despite class differences-welcomed into Meg's middle-class home.

Lurvy, the hired hand in Charlotte's Web, was likewise welcome at the Arable family dinner table of the 1950s. This attitude of acceptance is in line with Horatio Alger's understanding of the American Dream in which a family of means welcomes into their home a child who, although poor, shows aptitude and a willingness to work.

\section{Conclusion}

Peter F. Drucker saw us becoming a class society unless service workers can achieve income, dignity, and recognition. ${ }^{45}$
In the past thirty years, income disparities have grown, and class is more a determining factor in life outcomes than ever. Robert Putnam recalled more opportunities for children of different social classes to interact, and, accordingly, there were greater opportunities for the child from a poor family to achieve upward mobility in the 1950s. ${ }^{46}$

There is a link between storytelling and survival in times of economic insecurity. In previous generations, the stories of success written to the Alger formula could help fortify those working their way out of poverty. However, in Our Kids, Putnam argues that the American Dream is in crisis; the expectation of success may no longer exist as a viable story for children of the poor.

In 2015, Anne Case and Angus Deaton published the findings of their study conducted to identify the cause of the recent increase in the death rate among white working-class Americans. Many had lost the ability to work or suffered chronic pain; many died of suicide or drug abuse. In an interview, Deaton, a Nobel Prize-winning economist, offered the following explanation for the Case-Deaton findings: these individuals, who died in midlife, had "lost the narrative of their lives." ${ }^{47}$

In the years immediately following World War II, there was respect for the skills and grit of the working class. In Hemingway's The Old Man and the Sea, published in 1952, Santiago, the fisherman, was admired by the boy, his young friend, for his courage, skill, and dedication to craft. ${ }^{48}$ Recent Newbery Medal-winning novels may illuminate the preoccupations of middle-class children and their parents. However, we learn little about the stories that might sustain children from working-class families; lower-class parents and their children are barely visible in recent Newbery literature. ¿

\section{References}

1. Robert B. Putnam, Our Kids: The American Dream in Crisis (New York: Simon \& Schuster, 2015).

2. Susan B. Neuman, Changing the Odds for Children at Risk: Seven Essential Principles of Educational Programs That Break the Cycle of Poverty (Westport, CT: Praeger, 2009).

3. "America Reads," Library of Congress, accessed August 30, 2017, www.loc.gov/exhibits/america-reads/.

4. Horatio Alger Jr., Ragged Dick and Mark, the Match Boy: Two Novels by Horatio Alger (1869; repr. New York: Simon \& Schuster, 1962).

5. David M. Ellis, A History of New York State (Ithaca: Cornell University Press, 1967).

6. Anita Silvey, The Essential Guide to Children's Books and Their Creators (Boston: Houghton Mifflin, 2002); Rebecca J. Lukens, A Critical Handbook of Children's Literature (Boston: Allyn and Bacon, 2003).

7. Cynthia Kadohata, Kira-Kira (New York: Atheneum, 2004), 174. 
8. Ibid., 109.

9. Lynne Rae Perkins, Criss Cross (New York: HarperTrophy, 2008).

10. Ibid., 322.

11. Susan Patron, The Higher Power of Lucky (New York: Atheneum, 2006).

12. Kadohata, Kira-Kira, 152.

13. Jack Gantos, Dead End in Norvelt (New York: Farrar, Straus and Giroux, 2011).

14. Richard Russo, Mohawk (New York: Vintage Contemporary, 1986).

15. Matt de la Peña, Last Stop on Market Street (New York: Putnam, 2015).

16. Ibid.

17. Jonathan Kozol, The Shame of the Nation: The Restoration of Apartheid Schooling in America (New York: Crown, 2005).

18. Ibid., 77.

19. Ibid., 173.

20. Neuman, Changing the Odds for Children at Risk.

21. Rebecca Stead, When You Reach Me (New York: Random House/Wendy Lamb, 2009).

22. Madeleine L'Engle, $A$ Wrinkle in Time (New York: Farrar, Straus and Giroux, 1962).

23. Richard C. Anderson, Rand J. Spiro, and William E. Montague, eds., Schooling and the Acquisition of Knowledge (New York: John Wiley \& Sons, 1977).

24. Peter F. Drucker, Post-Capitalist Society (New York: HarperCollins, 1993).

25. L'Engle, $A$ Wrinkle in Time, 9.

26. Susan B. Neuman and Donna Celano, “The Knowledge Gap: Effects of Leveling the Playing Field for Low- and Middle-Income Children," Reading Research Quarterly 41 (2006): 176-201.

27. Malcolm Gladwell, Outliers: The Story of Success (New York: Back Bay Books, 2011).
28. Kwame Alexander, The Crossover (Boston: Houghton Mifflin Harcourt, 2014).

29. Patron, The Higher Power of Lucky.

30. Dana Gioia, Reading at Risk: A Survey of Literary Reading in America, Research Division Report 46 (Washington, DC: National Endowment for the Arts, 2005).

31. Drucker, Post-Capitalist Society.

32. Richard L. Florida, The Rise of the Creative Class: And How It's Transforming Work, Leisure, Community, and Everyday Life (New York: Basic Books, 2002).

33. Kate DiCamillo, Flora and Ulysses: The Illuminated Adventures (Somerville, MA: Candlewick Press, 2013).

34. Ibid., 55.

35. Ibid.

36. E. B. White, Charlotte's Web (New York: Harper \& Row, 1952).

37. Kozol, The Shame of the Nation, 77.

38. Neuman, Changing the Odds for Children at Risk.

39. Ibid.

40. Ibid., 14.

41. Margaret Wise Brown, Goodnight Moon (New York: Harper and Row, 1947).

42. William J. Bennett, First Lessons: A Report on Elementary Education in America (Washington, DC: Department of Education, 1986).

43. Ibid., 9 .

44. L'Engle, A Wrinkle in Time, 91.

45. Drucker, Post-Capitalist Society.

46. Putnam, Our Kids.

47. Paul Krugman, "Despair, American Style," New York Times, November 9, 2015, A23.

48. Ernest Hemingway, The Old Man and the Sea (New York: Scribner, 1952). 